\section{Variation in TaqI-digested DNA of Sugar and Black Maples Is Independent of Taxon and Plant Origin}

\author{
Rolston St. Hilaire ${ }^{1}$ and William R. Graves \\ Department of Horticulture, Iowa State University, Ames, IA 50011
}

Randall L. Small
Department of Botany, Iowa State University, Ames, IA 50011

Additional index words. Acer nigrum, Acer saccharum, cpDNA, ndhA, phylogeny

\begin{abstract}
Morphological distinctions between sugar maples and black maples are not consistently evident, and molecular assessment of genetic diversity is lacking for these taxa. We examined restriction-site polymorphisms in the $n d h A$ intron of the chloroplast DNA (cpDNA) in populations of sugar maples and black maples representing their zones of allopatry and sympatry in eastern North America. Restriction-site analysis of the $n d h A$ intron after digestion with HinfI and Sau3AI yielded no polymorphisms. Restriction digestion of the $n d h A$ intron with $\operatorname{Taq} I$ revealed two cpDNA haplotypes that were neither geographically localized nor taxon specific. Although testing additional accessions of sugar maples and black maples for cpDNA variation will further elucidate patterns of genetic variation, our initial results suggest that the taxa are either exchanging genes or share an ancestral cpDNA polymorphism.
\end{abstract}

Sugar maples (Acer saccharum Marsh.) are highly valued trees indigenous to eastern North America. They are frequently planted in designed landscapes because of their colorful foliage and the uniformity of their growth habit. Black maples [(Acer saccharum Marsh. ssp. nigrum Desm. (Desmarais, 1952) or Acer nigrum Michx. f. (Rehder, 1940)] share many attributes of sugar maples and may be particularly resilient when planted in harsh environments (St. Hilaire and Graves, 1999). Similarities in the traits and distribution of these maples lead to confusion about their taxonomy and genetic relatedness. The two taxa are sympatric from eastern Iowa to Vermont. Sugar

Received for publication 7 June 2001. Accepted for publication 17 Nov. 2001. Journal Paper No. J19395 of the Iowa Agriculture and Home Economics Experiment Station, Ames, Project No. 3603, and supported by Hatch Act and State of Iowa funds. ${ }^{1}$ Former Graduate Research Assistant. Current address: Dept. of Agronomy and Horticulture, Box 30003, New Mexico State Univ., Las Cruces, NM 88003-8003. E-mail address: rsthilai@nmsu.edu maples are allopatric to black maples east of Vermont, while populations of black maple are allopatric to sugar maples west of eastern Iowa (St. Hilaire and Graves, 1999). Improving our understanding of the relationship of these taxa would establish their phylogeny and would facilitate the selection and description of cultivars.

Molecular assessment of genetic diversity is lacking among sugar maples and black maples across a wide geographical region. Chloroplast DNA (cpDNA) variation is useful for studying genetic diversity because cpDNA is haploid, nonrecombinant, and often uniparentally and maternally inherited (McCauley, 1995; Olmstead and Palmer, 1994). Data on cpDNA variation have been used to address many biological and evolutionary issues, such as the phylogeny of angiosperms (Olmstead and Palmer, 1994), phylogeography of comal., 1996), and the postglacial colonization routes of European species of oaks (Quercus L.) (Petit et al., 1997). The $n d h A$ intron, which resides in the small single-copy region of mon beech (Fagus sylvatica L.) (Demesure et
cpDNA, can be useful for research on phylogeny (Small et al., 1998). We screened several cpDNA noncoding regions (data not presented) as described in Small et al. (1998), but only obtained reliable amplification or detected polymorphism in the $n d h A$ region. Thus, our objective was to conduct a preliminary assessment of the potential for using restriction-site variation in the $n d h A$ intron of cpDNA to assess genetic diversity of sugar maples and black maples in their zones of sympatry and allopatry.

\section{Materials and Methods}

We germinated seeds of the two taxa, arranged the individually potted seedlings randomly in a greenhouse, and grew them for 1 year. The seedlings were indigenous to zones of sympatry and allopatry for the taxa (Table 1). Young leaf blades were taken from each plant, frozen in liquid nitrogen, and stored at $-80{ }^{\circ} \mathrm{C}$. Total genomic DNA was extracted from $1.5 \mathrm{~g}$ of frozen tissue by using the method of Doyle and Doyle (1987), except that the extraction buffer was modified to contain $10 \%$ (w/v) PVP-40 (Eastman Kodak, Rochester, N.Y.). DNA was cleaned by using a protocol for tissues rich in polysaccharides, polyphenolics, and other PCR-inhibiting compounds (Lamboy and Alpha, 1998). DNA concentration was determined with a UV-VIS spectrophotometer (Lambda Bio; PerkinElmer, Norwalk, Conn.).

The degenerate primer-pair sequence for $n d h A$ is $n d h A$-F (5'-GGW CTT CTY ATG KCR GGA TAT RGM TC-3') and $n d h A-\mathrm{R}$ (5'-CTG YGC TTC MAC TAT ATC AAC TGT AC-3') (Small et al., 1998). Amplifications were performed in a $25-\mathrm{mL}$ volume by using a thermocycler (GeneAmp PCR system 2400, Perkin-Elmer). The reaction mixture contained: $15.78 \mathrm{~mL}$ of sterile, distilled $\mathrm{H}_{2} \mathrm{O}$; $10 \mathrm{~mm}$ Tris at $\mathrm{pH} 8.3 ; 2 \mathrm{~mm} \mathrm{MgCl}_{2} ; 50 \mathrm{~mm}$ $\mathrm{KCl} ; 0.001 \%$ gelatin; $0.5 \%$ NP-40 (Sigma, St. Louis); $0.4 \mathrm{~mm}$ of dNTPs; $0.2 \mathrm{~mm}$ each of forward primer and reverse primer; $60 \mathrm{ng}$ of template DNA, and 0.5 units of Taq polymerase (Promega, Madison, Wis.). PCR conditions were $5 \mathrm{~min}$ at $94^{\circ} \mathrm{C}$ followed by 30 cycles, each of $1 \mathrm{~min}$ at $94{ }^{\circ} \mathrm{C} ; 90 \mathrm{~s}$ at $42{ }^{\circ} \mathrm{C}$; and 2 min at $72{ }^{\circ} \mathrm{C}$.

Aliquots of PCR amplicons (5 mL) were digested with five units of the four-base recog-

Table 1. Regions of the United States and geographical origins of the 24 accessions that yielded amplification products from among the 107 sugar maples and black maples from which DNA was extracted. All accessions were native to the sites where they were sampled. The two maple taxa are sympatric in eastern Iowa. Black maples are allopatric to sugar maples in central Iowa. Sugar maples are allopatric to black maples in New Hampshire. Sugar maples are much more prevelant than black maples in Vermont and New York.

\begin{tabular}{|c|c|c|c|c|c|c|}
\hline Region & $\begin{array}{c}\text { Geographical } \\
\text { origin }\end{array}$ & $\begin{array}{c}\text { Latitude } \\
(\mathrm{N})\end{array}$ & $\begin{array}{l}\text { Longitude } \\
\text { (W) }\end{array}$ & $\begin{array}{c}\text { No. of } \\
\text { accessions }\end{array}$ & $\begin{array}{c}\text { Taxon based on } \\
\text { morphology }\end{array}$ & $\begin{array}{c}\text { cpDNA } \\
\text { haplotype }^{z}\end{array}$ \\
\hline \multirow[t]{3}{*}{ Central Iowa } & Pammel Woods & $42^{\circ} 30^{\prime} 15^{\prime \prime}$ & $93^{\circ} 31^{\prime} 40^{\prime \prime}$ & 1 & Black maple & $\mathrm{A}$ \\
\hline & Iowa State Univ. & $42^{\circ} 30^{\prime} 34^{\prime \prime}$ & $93^{\circ} 38^{\prime} 54^{\prime \prime}$ & 3 & Black maple & A \\
\hline & Dolliver Memorial State Park & $42^{\circ} 23^{\prime} 13^{\prime \prime}$ & $94^{\circ} 05^{\prime} 00^{\prime \prime}$ & 4 & Black maple & B \\
\hline \multirow[t]{3}{*}{ Eastern Iowa } & Palisades-Kepler State Park & $41^{\circ} 49^{\prime} 00^{\prime \prime}$ & $91^{\circ} 30^{\prime} 22^{\prime \prime}$ & 6 & Sugar maple & A \\
\hline & Palisades-Kepler State Park & $41^{\circ} 50^{\prime} 27^{\prime \prime}$ & $91^{\circ} 31^{\prime} 00^{\prime \prime}$ & 1 & Sugar maple & A \\
\hline & Backbone State Park & $42^{\circ} 36^{\prime} 58^{\prime \prime}$ & $91^{\circ} 33^{\prime} 34^{\prime \prime}$ & 3 & Sugar maple & $\mathrm{B}$ \\
\hline Northeastern & Strafford, N.H. & $43^{\circ} 17^{\prime} 39^{\prime \prime}$ & $71^{\circ} 04^{\prime} 39^{\prime \prime}$ & 1 & Sugar maple & A \\
\hline \multirow{2}{*}{ United States } & Underhill, Vt. & $44^{\circ} 31^{\prime} 33^{\prime \prime}$ & $72^{\circ} 56^{\prime} 44^{\prime \prime}$ & 3 & Sugar maple & A \\
\hline & Lake Placid, N.Y. & $44^{\circ} 16^{\prime} 46^{\prime \prime}$ & $73^{\circ} 58^{\prime} 49^{\prime \prime}$ & 2 & Sugar maple & A \\
\hline
\end{tabular}

${ }^{\mathrm{z}} \mathrm{A}$ denotes that two restriction sites were present; B denotes one restriction site. For all geographical locations with multiple accessions, all were the same haplotype. 
nition restriction endonucleases HinfI, Sau3AI, and TaqI. The incubation mixture had a total volume of $10 \mathrm{~mL}$. Incubations, $2.5 \mathrm{~h}$ each, were at $37^{\circ} \mathrm{C}$ (HinfI and Sau3AI) and $65^{\circ} \mathrm{C}$ (TaqI). Fragments from the DNA restriction digests were separated by electrophoresis on $3 \%$ agarose gel (NuSieve; FMC BioProducts, Rockland, Maine) in Tris-Borate-EDTA buffer, and they were stained with SYBR Green (FMC BioProducts). Gels were epiilluminated with UV light at $253.4 \mathrm{~nm}$ and photographed.

\section{Results}

We extracted DNA from 107 accessions, but only 24 yielded amplification products (Table 1). While the rate of yield was low, the 24 samples were from seedlings native to diverse geographical locations that included zones of allopatry and sympatry of the two species (Table 1). The restriction enzymes HinfI and Sau3AI had five and three restriction sites, respectively, but yielded no polymorphisms in any of the DNA samples.

Restriction digestion with $T a q \mathrm{I}$ revealed one or two restriction sites depending on the population that was sampled. We designated the cpDNA haplotype as A when two restriction sites were present and as B when one restriction site was present (Table 1). All accessions within a geographical location had the same number of restriction sites. Also, digests did not detect taxon-specific markers. For example, two TaqI restriction sites were present in all the sugar maples from the north- eastern United States. These restriction sites were shared with some sugar maples in eastern Iowa, and with some black maples indigenous to central Iowa (Table 1).

\section{Discussion}

Although many studies of variation in cpDNA involve very small sample sizes (Whittemore and Schaal, 1991), sampling additional accessions, and use of other locusenzyme combinations, are needed to reveal taxonomic or geographical patterns of genetic variation among sugar maples and black maples. Our initial assessment of the potential for using restriction-site variation with these taxa indicates that polymorphisms cannot be obtained by using HinfI or Sau3AI. We also have demonstrated that variation at the $n d h A$ locus after digesting with $T a q \mathrm{I}$ is independent of taxon and geographical region. Similarities in cpDNA from sugar maples in eastern Iowa and black maples in central Iowa (Table 1) indicate that either the taxa are exchanging genes via introgressive hybridization, or that they share an ancestral cpDNA polymorphism. Observations of trees with morphological characters intermediate between the two taxa led Desmarais (1952) to suggest that the species may introgressively hybridize. The lack of variation in cpDNA among multiple accessions within a location (Table 1) indicates that future research should be designed to examine plants from as many locations as possible, even if the number of samples within locations must be minimized to allow this.

\section{Literature Cited}

Demesure, B., B. Comps, and R.J. Petit. 1996. Chloroplast DNA phylogeography of the common beech (Fagus sylvatica L.) in Europe. Evolution 50:2515-2510.

Desmarais, Y. 1952. Dynamics of leaf variation in the sugar maples. Brittonia 7:347-388.

Doyle, J.J and J.L. Doyle. 1987. A rapid DNA isolation procedure for small quantities of fresh leaf tissue. Phytochem. Bul. 19:11-15.

Lamboy, W.F. and C.G. Alpha. 1998. Using simple sequence repeats (SSRs) for DNA fingerprinting germplasm accessions of grape (Vitis L.) species. J. Amer. Soc. Hort. Sci. 123:182188.

McCauley, D.E. 1995. The use chloroplast DNA polymorphism in studies on gene flow in plants. Trends in Ecol. Evol. 10:198-202.

Olmstead, R. G. and J.D. Palmer. 1994. Chloroplast systematics: a review of methods and data analysis. Amer. J. Bot. 85:1205-1224.

Petit, R.J., E. Pineau, B. Demesure, R. Bacilieri, A Ducousso, and A. Kremer. 1997. Chloroplast DNA footprints of postglacial recolonization by oaks. Proc. Natl. Acad. Sci. USA. 94:999610001.

Small, R.L., J.A. Ryburn, R.C. Cronn, T. Seelanan, and J.F. Wendel. 1998. The tortoise and the hare: Choosing between noncoding plastome and nuclear $A d h$ sequences for phylogeny reconstruction in a recently diverged plant group. Amer. J. Bot. 85:1301-1315.

St. Hilaire, R. and W.R. Graves. 1999. Foliar traits of sugar maples and black maples near $43^{\circ} \mathrm{N}$ latitude in eastern and central United States. J. Amer. Soc. Hort. Sci. 124:605-611.

Whittemore, A.T. and B.A. Schaal. 1991. Interspecific gene flow in sympatric oaks. Proc. Natl. Acad. Sci. USA. 88:2540-2544. 